\title{
Immunogenicity and Safety of La Sota Strain of Newcastle Disease Virus Administered to Newly Hatched Chicks by Nebulization
}

\author{
Hrvoje Mazija $^{1}$, Stanislav Čajavec $^{2}$, Estella Prukner-Radovčić ${ }^{1}$, Neda Ergotić 2 , \\ Irena Ciglar-Grozdanić ${ }^{1}$, Željko Gottstein ${ }^{1}$, Anita Kokić ${ }^{4}$, William L. Ragland ${ }^{3}$ \\ ${ }^{1}$ Department of Poultry Diseases with Clinic, Faculty of Veterinary Medicine, University of Zagreb, Croatia \\ ${ }^{2}$ Veterina d.d., Kalinovica, Rakov Potok, Croatia \\ ${ }^{3}$ Institut Ruđer Bošković, Zagreb, Croatia \\ ${ }^{4}$ Mostina d.o.o., Sinj, Croatia
}

Received January 14, 2008

Accepted October 1, 2008

\begin{abstract}
The objective of four trials performed on specific-pathogen-free and commercial chickens, either of light or heavy hybrids, was to evaluate the new vaccine delivery method to newly hatched chickens using commercial La Sota vaccine. The vaccine was given by means of nebulization using an ultrasonic device producing homologous aerosol of particles ranging 3-5 microns in diameter. Chickens were exposed to the La Sota vaccine for 30, 60 or $300 \mathrm{~s}$ in a closed chamber of the device, thus enabling constant particle size during vaccination. No adverse reaction to the given vaccine was recorded, and the immunity, developed no later than 7 days after vaccination, lasted for at least 49 days which was confirmed by challenge infection using Herts 33 strain of Newcastle disease virus. Maternal antibodies did not influence the development of immunity. Regarding the mode of vaccination, the described method is suitable for the control of Newcastle disease in both big poultry enterprises as well as small backyard flocks when newly hatched chickens are supplied from local hatcheries.
\end{abstract}

Ultrasonic nebulizer, chicks, vaccination, La Sota strain, immune response, Newcastle disease

Newcastle disease (ND) still remains a serious poultry health problem, causing mortality and therefore economic loss. Appearance of virulent ND viruses (vNDV) in different parts of the world (OIE 2008) requires repeated and expensive use of live and/or inactivated vaccines (Van Eck 1987). In spite of this, there are many recent reports of considerable economic loss due to mortality and cost of control of the disease (Leslie 2000; Capua et al. 2002). Live vaccines are prevalent because they allow mass application techniques, and spraying or aerosol application is preferred. Compared to vaccination via drinking water, aerosol vaccination is much more efficient causing high protection in a shorter period of time, and is less affected by maternal antibodies (Allan et al. 1978). Lentogenic strains like La Sota are immunogenic enough and widely used all over the world, but still have variable residual pathogenicity (Borland and Allan 1980). Mesogenic strains are certainly more immunogenic (Al-Garib et al. 2003) but used only in countries where ND is endemic. Both cause severe vaccine reactions that could be partly explained by their pathogenicity and the paucity of phagocytes in avian respiratory system and therefore lower activity against concurrent bacterial infections (Toth 2000).

Lentogenic strains can be used only in birds with a low level of or no maternal antibodies, but not in areas where ND is caused by virulent strains and is endemic. Chicks with a higher level of maternal antibodies vaccinated by the respiratory route while in the hatchery (Al-Garib et al. 2003) or in the first four days of life do not respond by specific antibody production but are still protected because of the local immunity developed, and secondary vaccination is required (Mazija et al. 1981). Specific resistance is achieved

Phone: +38512390280

Fax: +38512390280

E-mail:hmazija@vef hr

http://www.vfu.cz/acta-vet/actavet.htm 
after $60 \mathrm{~h}$ (Gough and Alexander 1973), which is very important in areas of high ND prevalence (Hutchinson 1975). Efficacy of aerosol vaccination depends mainly on the size of droplets and the patterns of the device used for aerosol generation (Villegas and Kleven 1976). Aerosol droplets of ND B1 vaccine diluted in distilled water were more immunogenic compared to droplets derived from vaccine diluents containing tap water or gelatine (Gough and Allan 1973).

Depending upon the age, the level of maternal antibodies and pressure of the disease, newly hatched chicks are usually primed using live vaccines given either by coarse spray (Allan et al. 1978) or by oculonasal instillation and later boosted using spray or application via drinking water. Additional application through feed is possible using thermostable Australian strain Queensland V4 (Ideris et al. 1990).

Successful vaccination against ND using strain NDV-6/10 of NDV and spraying device MASTERDROP ${ }^{\circledR}$ was described by Czifra et al. (1998). The vaccine was dissolved in distilled water containing stabilizer and day-old chicks were exposed to a dose of $10^{7.3}$ per $\mathrm{m}^{3}$ during $30 \mathrm{~min}$ according to Tamasi et al. (1988). The mean particle size when exhausted from the apparatus ranged $4 \mu$ in diameter. Compared to La Sota strain, NDV-6/10 caused fewer vaccine reactions, and was accompanied by better final body weight. The protection after challenge at 3, 4 and 6 weeks was $86 \%, 89 \%$ and $100 \%$, respectively.

The objective of the present study was to investigate the efficacy of a newly developed ultrasonic nebulizer SONOVAC 095 producing very small particles ranging 2 to 5 microns in diameter in vaccination with La Sota NDV of newly hatched chicks. The difference compared to other devices is the uniform aerosol particle size produced by ultrasound generator that remains constant in diameter owing to its construction. Additionally, it uses a shorter time $(30,60$ or $300 \mathrm{~s})$ of exposure to the virus aerosol compared to other authors. Previously the apparatus was used in the investigation of immunogenicity of $\mathrm{H} 120$ vaccine strain of infectious bronchitis (Mazija et al. 2000). The immune response following vaccination as well as protection to challenge was evaluated.

\section{Materials and Methods}

Vaccination and chickens

Commercially available freeze-dried NDV La Sota strain vaccine, PESTIKAL ${ }^{\circledR}$ LA SOTA SPF (VETERINA d.d., Croatia) was used in all experiments. The vaccine was suspended in distilled water and given by SONOVAC ${ }^{\circledR}$ 095 ultrasonic nebulizer (Plate X, Fig. 1) patented by Mazija and Štimac (1999).

The apparatus consists of two chambers holding a liquid to be nebulized. The nebulization source provides an ultrasonic output at a frequency of $2.1 \mathrm{MHz}$ that causes nebulization. The controlled amplitude of the nebulization source can vary in order to provide enough aerosol of the vaccine used. In all trials the apparatus was adjusted to the level of $4.5 \mathrm{ml}$ per minute. The apparatus creates a uniform size of particles, most of them $(95 \%)$ ranging 2 to 5 microns in diameter. This was confirmed using Type 2600D Continuous Spray Sizer (MALVERN, Worcestershire, England, UK, kindly provided by MICRON, Bromyard Industrial Estate, Bromyard, Herfordshire HR7 4HS, UK). Such aerosol does not wet the chicks and efficiently reaches the lower part of the respiratory system. The nebulizer was designed for small hatcheries and has a capacity of 6,000 to 12,000 day-old chicks per hour.

The chickens used in the first experiment were obtained from a commercial specific pathogen-free (SPF) flock (Charles River Farms Hungary, Budapest). All birds were confirmed as negative for NDV antibodies before used in the experiment. The chickens used in the other experiments were progenies of commercial NDV-vaccinated parent flocks.

Experimental design

Safety study of vaccination method was performed using two groups of 20 one-day-old SPF chickens. One group was exposed for $60 \mathrm{~s}$ to a fine aerosol of $5 \times 10^{7.6} \mathrm{EID}_{50}$ of vaccine per bird, while the second group remained unvaccinated and served as control. Five chicks were randomly selected from each group on the $7^{\text {th }}$ day and on the $14^{\text {th }}$ day and were challenged with virulent Herts 33 NDV strain as described.

A total of 120 one-day-old commercial broilers (Hybro, "Koka", Varaždin, Croatia) in Experiment II were divided into three groups of 40 chicks. Two groups were exposed to a fine aerosol of vaccine for 30 (group A1) and 300 (A2) s, while the third group (A3) remained unvaccinated and served as control. Regarding the time of exposure, the chicks exposed to aerosol for $30 \mathrm{~s}$ were offered $2.5 \times 10^{7.6}$ and for 
$300 \mathrm{~s} 25 \times 10^{7.6} \mathrm{EID}_{50}$ of the vaccine virus per bird. The dose was adjusted according to the efficacy of aerosol generated up to $4.5 \mathrm{ml}$ per min of suspension and the quantity of vaccine virus which was administrated to chicks during the 30 and $300 \mathrm{~s}$ of exposure. The dose was calculated as the volume of vaccine having a known titre that was nebulized during the time the chicks were exposed; e.g. 100 chickens were vaccinated with 100 doses diluted in $4.5 \mathrm{ml}$ and nebulized during $60 \mathrm{~s}$. Ten chicks from each group were challenged on the $21^{\text {st }}$ day with the virulent Herts 33 NDV strain. The same was done on the $42^{\text {nd }}$ day with fifteen chickens remaining from each group.

A total of 180 day-old male chicks of light hybrids (Lohmann Brown, "Agrokoka" Božjakovina, Croatia) were used in Experiment III. Two groups of 60 chicks were exposed to the nebulized vaccine for 30 (group B1) or $300 \mathrm{~s}$ (group B2) while 60 chicks of the same origin served as control (B3) and were not vaccinated. The doses of vaccine virus used were the same as in Experiment II. Twenty chicks were randomly selected from each group on the $21^{\text {st }}$ and $42^{\text {nd }}$ day and challenged with the virulent Herts 33 NDV strain.

A total of 240 day-old male chicks of light hybrids (Lohmann Brown, "Agrokoka" Božjakovina, Croatia) in Experiment IV were divided into two groups of 120 chicks. First group (C1) of day-old male chicks was exposed to fine aerosol of vaccine for $60 \mathrm{~s}$ and were offered $5 \times 10^{7.6} \mathrm{EID}_{50}$ of the vaccine virus per bird, and the control group (C2) was not treated at all. Starting from the $7^{\text {th }}$ day of life, 15 chickens were randomly selected from each group and challenged with the virulent NDV strain Herts 33 at weekly intervals up to the $49^{\text {th }}$ day.

Challenge

All challenges were performed using $10^{6.0} \mathrm{ELD}_{50}$ of the velogenic NDV strain Herts 33 by the intramuscular route. After challenge, the birds were monitored 10 (Experiment I, IV) or 14 (Experiment II, III) days for clinical signs of disease (respiratory signs, muscular tremor, torticollis, and paralysis of wings and legs) and mortality. Chicks without clinical signs of ND were considered as protected; those that showed the typical neurological signs or died within this period were considered as dead and not protected. Re-isolation of challenge virus from five carcasses in each experiment was performed to confirm the clinical finding of ND. For this purpose, five SPF chicken embryos were inoculated with water suspension of brain tissue.

\section{Serological methods}

Blood for serological tests was taken by heart puncture on the first day of life, and then at weekly intervals from the wing vein until the $49^{\text {th }}$ day after vaccination, as well as 10 days or two weeks after challenge. All sera collected were inactivated for $30 \mathrm{~min}$ at $56^{\circ} \mathrm{C}$ and examined by the haemagglutination inhibition (HI) test (beta micro method) using 4 haemagglutinating units (Allan and Gough 1974) of inactivated La Sota virus (Experiment I-III) or by ELISA for ND (FlockCheck ${ }^{\mathbb{Q}}$, IDEXX, Portland, Maine, USA) (Experiment IV). The ELISA titre compares the absorbance with the positive control cut-off value. Inhibition of haemagglutination at a serum dilution of $\log _{2} 4$ was considered as positive. Sera were analysed for presence of maternal antibodies as well as for the active response to vaccine and challenge virus.

\section{Statistical methods}

Treatment means were compared by rank sums analysis using the JMP program (SAS Institute, Cary, NC). Data for protection to challenge were analysed by log likelihood and Fisher's exact tests. Differences of $p \leq 0.05$ were considered significant.

\section{Results}

No clinical reaction was observed in vaccinated chicks regardless of the length of exposure in the nebulizer $(30,60$ or $300 \mathrm{~s})$.

Antibody titres to NDV of vaccinated birds are presented in Table 1. As expected, all non-vaccinated control SPF birds were free of HI NDV antibodies throughout Experiment I.

Table 1. The HI titres $\left(\log _{2}\right)$ of specific antibodies to NDV of SPF chickens after aerosol vaccination against Newcastle disease in Experiment I

\begin{tabular}{|l|c|c|c|c|c|c|c|}
\hline \multirow{3}{*}{ Groups } & \multicolumn{7}{|c|}{ HI titre $^{1}$} \\
\cline { 2 - 8 } & \multicolumn{7}{|c|}{ Days after vaccination } \\
\cline { 2 - 8 } & 0 & 7 & 14 & 21 & 28 & 35 & 42 \\
\hline \multirow{2}{*}{ Control } & 0 & 0 & 0 & 0 & 0 & 0 & 0 \\
& $(7)$ & $(7)$ & $(7)$ & $(7)$ & $(7)$ & $(7)$ \\
\hline La Sota-60s s & 0 & $\begin{array}{c}2.20 \pm 1.79 \\
(7)\end{array}$ & $\begin{array}{c}2.80 \pm 1.10 \\
(5)\end{array}$ & $\begin{array}{c}6.60 \pm 1.52 \\
(5)\end{array}$ & $\begin{array}{c}7.20 \pm 1.30 \\
(5)\end{array}$ & $\begin{array}{c}6.80 \pm 1.10 \\
(5)\end{array}$ & $\begin{array}{c}5.00 \pm 1.22 \\
(5)\end{array}$ \\
\hline
\end{tabular}

${ }^{1}$ Mean $\log _{2} \mathrm{HI}$ titre to $\mathrm{ND} \pm \mathrm{SD}$ (number of samples) 
Results of HI titres of Experiment II and III are presented in Table 2. HI antibodies to NDV after decreasing until the $7^{\text {th }}$ day (1.7 to 2.1) (Experiment II) started to increase up to the $49^{\text {th }}$ day in the range from 2.6 to 4.67 in group A1 and from 3.29 to 4.62 in group A2. Maternal antibodies declined on day 7 and could not be detected thereafter. Significant difference in the HI titre between vaccinated (A1, A2) groups and unvaccinated controls appeared on day $14^{\text {th }}$ and lasted up to the $21^{\text {st }}$ day after vaccination. On day 28 after vaccination, group A2 exposed to the vaccine for $300 \mathrm{~s}$ had a significantly higher titre than A1 group. After the $42^{\text {nd }}$ day up to the end of the trial the differences were not significant. Unvaccinated chickens (A3 group) were free of HI antibodies to NDV on the $14^{\text {th }}$ day of age.

Table 2. The HI titres $\left(\log _{2}\right)$ of specific antibodies to NDV of commercial broilers (Hybro) in Experiment II male chickens of light hybrids in Experiment III after aerosol vaccination against Newcastle disease

\begin{tabular}{|c|c|c|c|c|c|c|c|c|c|}
\hline \multirow{3}{*}{$\begin{array}{l}\text { Exper. } \\
\text { number }\end{array}$} & \multirow{3}{*}{ Groups } & \multicolumn{8}{|c|}{ HI titre ${ }^{1}$} \\
\hline & & \multicolumn{8}{|c|}{ Days after vaccination } \\
\hline & & 0 & 7 & 14 & 21 & 28 & 35 & 42 & 49 \\
\hline \multirow{9}{*}{ II } & & $3.50^{\mathrm{A}, \mathrm{a}}$ & $2.10^{\mathrm{B}, \mathrm{b}}$ & $3.40^{\mathrm{A}, \mathrm{a}}$ & $3.92^{\mathrm{A}, \mathrm{a}}$ & $3.15^{\mathrm{B}, \mathrm{a}}$ & $2.60^{\mathrm{A}, \mathrm{b}}$ & $3.60^{\mathrm{A}, \mathrm{a}}$ & $4.67^{\mathrm{A}, \mathrm{c}}$ \\
\hline & $\mathrm{A} 1-30 \mathrm{sec}$ & \pm 1.16 & \pm 0.74 & \pm 1.07 & \pm 0.86 & \pm 0.90 & \pm 1.06 & \pm 1.06 & \pm 1.40 \\
\hline & & (14) & (10) & (10) & (13) & (13) & $(15)$ & (15) & (15) \\
\hline & & $3.50^{\mathrm{A}, \mathrm{a}}$ & $2.00^{\mathrm{B}, \mathrm{b}}$ & $3.50^{\mathrm{A}, \mathrm{a}}$ & $4.20^{\mathrm{A}, \mathrm{c}}$ & $4.62^{\mathrm{A}, \mathrm{c}}$ & $3.67^{\mathrm{B}, \mathrm{a}}$ & $3.29^{\mathrm{A}, \mathrm{a}}$ & $4.13^{\mathrm{A}, \mathrm{c}}$ \\
\hline & A2- $300 \mathrm{sec}$ & \pm 1.16 & \pm 0.94 & \pm 0.53 & \pm 1.01 & \pm 1.33 & \pm 0.82 & \pm 0.91 & \pm 0.92 \\
\hline & & (14) & (10) & (10) & (15) & (13) & (15) & (14) & (15) \\
\hline & & $3.50^{\mathrm{A}, \mathrm{a}}$ & $1.70^{\mathrm{B}, \mathrm{b}}$ & & & & & & \\
\hline & A3-Control & \pm 1.16 & \pm 0.82 & $0^{\mathrm{B}, \mathrm{c}}$ & $0^{\mathrm{B}, \mathrm{c}}$ & $0^{\mathrm{C}, \mathrm{c}}$ & $0^{\mathrm{C}, \mathrm{c}}$ & $0^{\mathrm{B}, \mathrm{c}}$ & $0^{\mathrm{B}, \mathrm{c}}$ \\
\hline & & (14) & (10) & (10) & (14) & (14) & (15) & (14) & (12) \\
\hline \multirow{9}{*}{ III } & & $5.00^{\mathrm{A}, \mathrm{a}}$ & $4.55^{\mathrm{A}, \mathrm{B}, \mathrm{a}, \mathrm{b}}$ & $4.85^{\mathrm{A}, \mathrm{a}}$ & $5.11^{\mathrm{A}, \mathrm{a}}$ & $3.33^{\mathrm{A}, \mathrm{c}}$ & $4.15^{\mathrm{A}, \mathrm{b}, \mathrm{c}}$ & $3.60^{\mathrm{A}, \mathrm{b}, \mathrm{d}}$ & $2.40^{\mathrm{A}, \mathrm{c}, \mathrm{d}}$ \\
\hline & $\mathrm{B} 1-30 \mathrm{sec}$ & \pm 1.13 & \pm 1.10 & \pm 0.81 & \pm 0.76 & \pm 1.14 & \pm 0.81 & \pm 0.89 & \pm 0.55 \\
\hline & & (15) & (20) & (20) & (18) & (18) & (20) & (5) & (5) \\
\hline & & $5.00^{\mathrm{A}, \mathrm{a}}$ & $5.20^{\mathrm{B}, \mathrm{a}}$ & $4.85^{\mathrm{A}, \mathrm{a}}$ & $4.70^{A, a}$ & $3.20^{\mathrm{A}, \mathrm{b}}$ & $3.32^{\mathrm{B}, \mathrm{b}}$ & $3.20^{\mathrm{A}, \mathrm{b}}$ & $2.4^{\mathrm{A}, \mathrm{b}}$ \\
\hline & B2-300 sec & \pm 1.13 & \pm 0.95 & \pm 0.67 & \pm 1.08 & \pm 1.24 & \pm 0.89 & \pm 0.79 & \pm 0.70 \\
\hline & & (15) & $(20)$ & (20) & (20) & (20) & (19) & (10) & (10) \\
\hline & & $5.00^{\mathrm{A}, \mathrm{a}}$ & $4.65^{\mathrm{A}, \mathrm{a}}$ & $3.79^{\mathrm{B}, \mathrm{b}}$ & $3.15^{\mathrm{B}, \mathrm{c}}$ & $1.20^{\mathrm{B}, \mathrm{d}}$ & $1.85^{\mathrm{C}, \mathrm{e}}$ & $1.60^{\mathrm{B}, \mathrm{e}}$ & $0.95^{\mathrm{B}, \mathrm{d}}$ \\
\hline & B3-Control & \pm 1.13 & \pm 1.35 & \pm 0.70 & \pm 0.59 & \pm 0.41 & \pm 0.81 & \pm 0.68 & \pm 0.51 \\
\hline & & (15) & (20) & (14) & (20) & $(20)$ & (20) & (20) & (20) \\
\hline
\end{tabular}

${ }^{1}$ Mean $\log ^{2} \mathrm{HI}$ titre to ND $\pm \mathrm{SD}$ (number of samples)

a,b,c Means in each row with a different lower alphabetic superscript are different at $p \leq 0.05$

${ }_{A, B, C}$ Means in each column with a different upper case alphabetic superscript are different at $p \leq 0.05$

Maternal HI antibody titres in chicks of light hybrids $\left(5.0 \log _{2}\right)$ (Experiment III) declined steadily and were no longer at a protective level on day 28. Both vaccinated groups of chicks had similar HI titres up to the $21^{\text {st }}$ day, reaching values of 5.11 and $4.70 \log _{2}$, and titres declined to 3.60 and $3.20 \log _{2}$ respectively, but were still protective.

Results of serological examination of vaccinated and unvaccinated groups in Experiment IV are presented in Table 3. There were no significant differences in titres among groups until 28 days when they began to rise in the vaccinated group, reaching the highest titre on the $35^{\text {th }}$ day. Titres in the control groups continued to decline reaching negligible levels on the $21^{\text {st }}$ day but a slight increase was detected from day 35 to 49.

Serological response and survival of chickens following challenge with Herts 33 All SPF birds in the challenged control group displayed conjunctivitis and severe depression from day 2-4 post challenge and $100 \%$ mortality was observed 5 days p.c. (Table 4 ). Contrary to 
Table 3. ELISA ${ }^{1}$ ND titres of male chickens of light hybrids after aerosol vaccination for ND in Experiment IV

\begin{tabular}{|l|c|c|c|c|c|c|c|c|c|}
\hline \multirow{3}{*}{ Groups } & \multicolumn{9}{|c|}{ ELISA titre $^{1}$} \\
\cline { 2 - 9 } & \multicolumn{9}{|c|}{ Days after vaccination } \\
\cline { 2 - 9 } & 0 & 7 & 14 & 21 & 28 & 35 & 42 & 49 \\
\hline \multirow{3}{*}{ C1-60 s } & $3151^{\mathrm{A}, \mathrm{a}}$ & $3896^{\mathrm{A}, \mathrm{a}}$ & $836^{\mathrm{A}, \mathrm{b}}$ & $307^{\mathrm{A}, \mathrm{c}}$ & $1480^{\mathrm{A}, \mathrm{b}}$ & $3328^{\mathrm{A}, \mathrm{a}}$ & $1857^{\mathrm{B}, \mathrm{b}}$ & $1545^{\mathrm{A}, \mathrm{b}}$ \\
& \pm 2033 & \pm 3336 & \pm 523 & \pm 263 & \pm 1442 & \pm 2376 & \pm 1485 & \pm 1276 \\
& $(20)$ & $(10)$ & $(20)$ & $(20)$ & $(20)$ & $(20)$ & $(17)$ & $(15)$ \\
\hline \multirow{3}{*}{ C2-control } & $3151^{\mathrm{A}, \mathrm{a}}$ & $1380^{\mathrm{B}, \mathrm{b}}$ & $569^{\mathrm{A}, \mathrm{c}}$ & $72^{\mathrm{D}, \mathrm{d}}$ & $1^{\mathrm{C}, \mathrm{e}}$ & $0^{\mathrm{C}, \mathrm{e}}$ & $27^{\mathrm{C}, \mathrm{f}}$ & $195^{\mathrm{B}, \mathrm{g}}$ \\
& \pm 2033 & \pm 1530 & \pm 475 & \pm 58 & \pm 2 & \pm 0 & \pm 29 & \pm 139 \\
& $(20)$ & $(10)$ & $(18)$ & $(19)$ & $(19)$ & $(17)$ & $(15)$ & $(15)$ \\
\hline
\end{tabular}

${ }^{1}$ Mean ELISA titre to ND $\pm \mathrm{SD}$ (number of samples)

${ }_{A, B, C, D}$ Means in each column with a different upper case alphabetic superscript are different at $p \leq 0.05$

a,b,c,d,e,f,g Means in each row with a different lower case alphabetic superscript are different at $p \leq 0.05$

Table 4. Serological response and survival of SPF chickens 10 days after challenge with Herts 33 virus in Experiment I

\begin{tabular}{|c|c|c|c|c|}
\hline \multirow{2}{*}{ Day of challenge } & \multicolumn{3}{|c|}{ Group } \\
\cline { 2 - 5 } & \multicolumn{2}{|c|}{ La Sota-60 s } & HI titre & Control \\
\cline { 2 - 5 } & HI titre & Protected $^{2}$ & - & $0 / 5$ \\
\hline 7 & $\begin{array}{c}8.67 \pm 0.58 \\
(3)\end{array}$ & $3 / 5$ & - & $0 / 5$ \\
\hline \multirow{2}{*}{14} & $\begin{array}{c}7.70 \pm 0.50 \\
(5)\end{array}$ & $5 / 5$ & & \multirow{2}{*}{} \\
\hline
\end{tabular}

${ }^{1}$ Mean $\log _{2}$ HI titre to $\mathrm{ND} \pm \mathrm{SD}$ (number of samples)

${ }^{2}$ No. of birds surviving /No. of birds challenged

that, $60 \%$ of vaccinated SPF bird survived challenge on day 7 , and $100 \%$ survived challenge on day 14.

Vaccination of one-day-old commercial chicks with nebulized La Sota strain provided high $(100 \%)$ protection against challenge with Herts 33 ND virus. There were no differences between the results of challenge at 21 and 42 days post vaccination (Table 5 ), and all chickens survived. Similarly, challenge at weekly intervals, from the $7^{\text {th }}$ up to the $49^{\text {th }}$ day of life day in Experiment IV (Table 6) indicates that $99 \%$ of the chickens vaccinated by means of nebulization during $60 \mathrm{~s}$ were protected. Antibody titres detected after NDV challenge by HI test (Experiment I-III) or ELISA test (Experiment IV) in all experiments significantly increased (Tables 4,6 ). Challenge virus was re-isolated from each of 5 carcases in all experiments.

\section{Discussion}

No clinical reaction was recorded to the La Sota vaccine regardless of the duration of exposure (30, 60 or $300 \mathrm{~s})$.

Results of challenge experiments have demonstrated that vaccination of newly hatched chicks with homogenous aerosol of fine particles of $\mathrm{La}$ Sota vaccine is a safe and effective way of inducing long-lasting specific resistance to Herts 33 strain of ND virus. It is developed at least 7 days (Tables 4,6) after vaccination and lasts for at least 49 days. Maternal NDV antibodies did not interfere with vaccine immunity due to the cellular immunity developed that was confirmed by challenge infection (Al-Garib et al. 2003). Little or no maternal antibody titres were observed for control birds on days 21 and 28 (Table 2), but some protection from challenge and high post-challenge antibody titres indicates a secondary response. 
Table 5. Serological response to NDV Herts 33 and survival of commercial broilers in Experiment II and male chickens of light hybrids in Experiment III 14 days after challenge on day 21 or day 42 of age

\begin{tabular}{|c|c|c|c|c|c|c|}
\hline \multirow{4}{*}{$\begin{array}{c}\text { Day of } \\
\text { challenge }\end{array}$} & \multicolumn{6}{|c|}{ Experiment II } \\
\hline & \multicolumn{6}{|c|}{ GROUP } \\
\hline & \multicolumn{2}{|c|}{$\mathrm{A} 1-30 \mathrm{~s}$} & \multicolumn{2}{|c|}{$\mathrm{A} 2-300 \mathrm{~s}$} & \multicolumn{2}{|c|}{ A3-Control } \\
\hline & HI titre $^{1}$ & Protected $^{2}$ & HI titre & Protected & HI titre & Protected \\
\hline 21 & $\begin{array}{c}8.9 \pm 1.27 \\
(9)\end{array}$ & $10 / 10$ & $\begin{array}{c}8.4 \pm 0.70 \\
(10)\end{array}$ & $10 / 10$ & - & $0 / 10$ \\
\hline \multirow[t]{3}{*}{42} & $\begin{array}{c}10.5 \pm 0.74 \\
(15)\end{array}$ & $15 / 15$ & $\begin{array}{c}10.3 \pm 0.74 \\
(15)\end{array}$ & $15 / 15$ & $\begin{array}{c}9.33 \pm 1.15 \\
\text { (3) }\end{array}$ & $3 / 15$ \\
\hline & \multicolumn{6}{|c|}{ Experiment III } \\
\hline & \multicolumn{2}{|c|}{$\mathrm{B} 1-30 \mathrm{~s}$} & \multicolumn{2}{|c|}{$\mathrm{B} 2-300 \mathrm{~s}$} & \multicolumn{2}{|c|}{ B3-Control } \\
\hline 21 & $\begin{array}{c}7.63 \pm 0.92 \\
(11)\end{array}$ & $20 / 20$ & $\begin{array}{c}9.11 \pm 0.78 \\
\text { (9) }\end{array}$ & $20 / 20$ & - & $0 / 20$ \\
\hline 42 & $\begin{array}{c}10.00 \pm 1.42 \\
\text { (11) }\end{array}$ & $20 / 20$ & $\begin{array}{c}10.70 \pm 1.06 \\
(10)\end{array}$ & $20 / 20$ & 9 & $1 / 20$ \\
\hline
\end{tabular}

${ }^{1}$ Mean $\log _{2} \mathrm{HI}$ titre to ND $\pm \mathrm{SD}$ (number of samples)

${ }^{2}$ No. of birds surviving /No. of birds challenged

Table 6. ELISA ND titres and survival of male chickens of light hybrids 10 days after challenge with Herts 33 virus in Experiment IV

\begin{tabular}{|c|c|c|c|c|}
\hline \multirow{3}{*}{ Day of challenge } & \multicolumn{4}{|c|}{ Group } \\
\hline & \multicolumn{2}{|c|}{$\mathrm{C} 1-60 \mathrm{~s}$} & \multicolumn{2}{|c|}{ C2-Control } \\
\hline & ELISA ND titres $^{1}$ & Protected $^{2}$ & ELISA ND titres & Protected \\
\hline 7 & $\begin{array}{c}4500 \pm 2336 \\
(10)\end{array}$ & $15 / 15$ & $\begin{array}{c}2656 \pm 3829 \\
(20)\end{array}$ & $12 / 15$ \\
\hline 14 & $\begin{array}{c}16607 \pm 6932 \\
(10)\end{array}$ & $14 / 15$ & $\begin{array}{c}11906 \pm 4785 \\
(20)\end{array}$ & $14 / 15$ \\
\hline 21 & $\begin{array}{c}27843 \pm 8492 \\
(10)\end{array}$ & $15 / 15$ & $\begin{array}{c}1848 \pm 7167 \\
(15)\end{array}$ & $10 / 15$ \\
\hline 28 & $\begin{array}{c}30014 \pm 2898 \\
(10)\end{array}$ & $15 / 15$ & $\begin{array}{c}14483 \pm 7551 \\
(8)\end{array}$ & $7 / 15$ \\
\hline 35 & $\begin{array}{c}20638 \pm 5573 \\
(10)\end{array}$ & $15 / 15$ & $\begin{array}{c}14665 \pm 6633 \\
\text { (3) }\end{array}$ & $3 / 15$ \\
\hline 42 & $\begin{array}{c}25221 \pm 3340 \\
(10)\end{array}$ & $15 / 15$ & $\begin{array}{c}22079 \pm 899 \\
\text { (2) }\end{array}$ & $2 / 10$ \\
\hline 49 & $\mathrm{nd}^{3}$ & $15 / 15$ & $\mathrm{nd}^{3}$ & $2 / 15$ \\
\hline
\end{tabular}

${ }^{1}$ Mean ELISA titre to ND $\pm \mathrm{SD}$ (number of samples)

${ }^{2}$ No. of birds surviving /No. of birds challenged

${ }^{3}$ not done

Early and effective response to the La Sota vaccine could be addressed to the extremely high amount of the vaccine virus entering deeper, probably into the whole respiratory system, compared to conventional spray vaccination, when the aerosol particles are blocked in the upper part of it (Hayter and Besch 1974; Mazija et al. 2001; Villegas and Kleven 1976). Thus, specific resistance to the Herts 33 NDV strain achieved early after vaccination is rather a result of cell-mediated immunity than specific antibody formation (Al-Garib et al. 2003).

Aerosols of La Sota vaccines used heretofore have caused severe vaccine reactions and for this reason have usually been limited to booster vaccinations. The aerosol vaccination described did not cause vaccine reactions, presumably because of the homogenous particle sizes that easily penetrate deep into the respiratory system, and because of paucity of macrophages in the respiratory system of chickens (Toth 2000). 
Since the nebulizer is constructed with a closed chamber, the size of particle produced remains constant in a high humidity atmosphere and the particles do not desiccate as is the case with all other aerosol devices (Gough and Allan 1973, 1976). Therefore, the efficacy of nebulization can be further explained by the uniform particle size and the use of distilled water as a vaccine diluent (Gough and Allan 1973). The presence of relatively high (Table 2) levels of maternal antibodies in chickens of light hybrids did not influence the specific response to the given vaccine. Vaccinated chicks resisted challenge infection already on day 7 of life (Table 4, 6) and remained resistant at least up to day 49 (Table 6) which is indicated by the still protective level of specific HI antibodies (Allan et al. 1978). The paucity of free-residing macrophages in the respiratory system of birds (Toth and Siegel 1986) could offer another explanation of the high level of immunity developed immediately after vaccination. The multiplication of La Sota virus in the respiratory system starts in all epithelial cells before phagocytic potential of macrophages is significantly increased (Chu and Dietert 1988), and already "occupied" cells with La Sota virus interfere with the homologous challenge virus ( $\mathrm{Li}$ and Hanson 1989; Mentkevich and Zhdanova 1971) making the vaccinated chickens resistant to field NDV. Local immunity against ND at the site of vaccine (Malkinson and Small 1977) in the case of nebulization comprises the whole respiratory system, thus enabling early development of specific resistance. Fine spray vaccination proved to be safe regardless of the level of maternal antibodies. Fewer vaccinations needed, e.g. only one for broilers, will also decrease the possibility of generating velogenic ND viruses from non-pathogenic strains commonly used in most of the world poultry production (Shengqing at al. 2002). Our results indicate that nebulization of La Sota vaccine could bring about significant improvement in controlling Newcastle disease in most of the developing countries where newly hatched chicks are supplied by small local hatcheries. Consequently, aerosol vaccination using La Sota vaccines may now be a feasible method of primary vaccination.

\section{Imunigenita a bezpečnost vakcíny z kmene La Sota Newcastleské choroby aplikované nebulizací kuřatům po vylíhnutí}

Cílem těchto 4 studií prováděných na lehkých a masných hybridech vylíhnutých kuřat pocházejících z SPF (specific-pathogen-free) a komerčních chovů, bylo zhodnotit nový způsob aplikace komerční vakcíny La Sota proti Newcastleské chorobě. Vakcína byla za použití ultrazvuku převedena na formu aerosolu s částicemi o velikosti $3-5 \mu \mathrm{m}$. Kuřata byla vystavená La Sota vakcíně po dobu 30, 60 nebo 300 s v uzavřené komoře zajišt’ující konstantní velikost částic během nebulizace. Žádná nepříznivá reakce na danou vakcínu nebyla zaznamenána. Postvakcinační protilátky se vytvořily do 7 dnů po vakcinaci a zajišt’ovaly obranyschopnost proti této chorobě po dobu nejméně 49 dnů, která byla potvrzena čelenžním vystavením viru Newcastleské nemoci - Herts 33. Mateřské protilátky neovlivňovaly vývoj odolnosti. Vzhledem k účinnosti vakcinace lze popisovanou metodu používat jako vhodný způsob prevence onemocnění virem Newcastleské choroby, jak na velkých drůbežích farmách tak u malochovatelů s domácí líhní kuřat.

\section{Acknowledgement}

The investigation was partly supported by the Ministry of Science and Technology of the Republic of Croatia, Grants No. 053-053-1863-1858 and No. 053-053-1863-1857.

Stanislav Čajavec deceased, October 9, 2008.

\section{References}

AL-GARIB SO, GIELKENS ALJ, GRUYS E, KOCH G 2003: Review of Newcastle disease virus with particular references to immunity and vaccination. Worlds Poult Sci J 59: 185-200 
ALLAN WH, GOUGH RE 1974: A standard haemagglutination inhibition test for Newcastle disease. 1. A comparison of macro and micro methods. Vet Rec 95: 120-123

ALLAN WH, LANCASTER JE, TOTH BL 1978: Newcastle disease vaccines: their production and use. FAO Press, Rome, Italy, pp. 93-108

BORLAND LJ, ALLAN WH, 1980: Laboratory tests for comparing live lentogenic Newcastle disease vaccines. Avian Pathol 9: 45-59

CAPUA I, DALLA PM, MUTINELLI F, MARANGON S, TERREGINO C 2002: Newcastle disease outbreaks in Italy during 2000: Vet Rec 150: 565-568

CHU Y, DIETERT RR 1988: The chicken macrophage response to carbohydrate-based irritants: temporal changes in peritoneal cell populations. Dev Comp Immunol 12: 109-119

CZIFRA G, MÉSZÁROS J, HORVÁTH E, MOVING V, ENGSTRÖM BE 1998: Detection of NDV-specific antibodies and the level of protection provided by single vaccination in young chickens. Avian Pathol 27: $562-565$

GOUGH RE, ALEXANDER DJ 1973: The speed of resistance to challenge induced in chickens vaccinated by different routes with a B1 strain of live Newcastle disease virus (NDV). Vet Rec 92: 563-564

GOUGH RE, ALLAN WH 1973: Aerosol vaccination against Newcastle disease: the influence of vaccine diluent. Vet Rec 93: 458-461

GOUGH RE, ALLAN WH 1976: Aerosol vaccination against Newcastle disease using Ulster strain. Avian Pathol 5: $81-95$

HAYTER RB, BESCH EL 1974: Airborne-particle deposition in the respiratory tract of chickens. Poult Sci 53:1507-1511

HUTCHINSON HL 1975: The control and eradication of Newcastle disease in Northern Ireland. Vet Rec 96: 213-217

IDERIS A, IBRAHIM AL, SPRADBROW PB 1990: Vaccination of chickens against Newcastle disease with a food pellet vaccine. Avian Pathol 19: 371-384

LESLIE J 2000: Newcastle disease: outbreak losses and control policy costs. Vet Rec 146: 603-606

LI X, HANSON RP 1989: In vivo interference by Newcastle disease virus in chickens, the natural host of the virus. Arch Virol 108: 229-245

MALKINSON M, SMALL PA Jr 1977: Local immunity against Newcastle disease virus in the newly hatched chicken's respiratory tract. Infect Immun 16: 587-592

MAZIJA H, BIĐIN Z, ŠTAJER A, MIKEC M 1981: Vakcinacija iz nužde kokoši protiv atipične kuge peradi (Emergency vaccination against Newcastle disease). Praxis vet 29: 45-52

MAZIJA H, CIGLAR GROZDANIĆ I, PRUKNER-RADOVČIĆ E, ČAJAVEC S, RAGLAND WL 2001: Immunogenicity of three vaccine strains of Newcastle disease virus given by nebulization. In: Abstracts of the International poultry scientific forum, January 15-16, 2001, Atlanta, Georgia.

MAZIJA H, ŠTIMAC T 1999: P950425A Ultrasonic atomizer for vaccines against Marek's disease and other poultry diseases. Croatian Intellectual Property Gazette 6: 877

MAZIJA H, ČAJAVEC S, CIGLAR GROZDANIĆ I, PRUKNER-RADOVČIĆ E, CVITAN R 2000: Comparative investigation of fogging in vaccine administration against IBD, strain H 120 (BRONHIKAL SPF ${ }^{\circledR}$ PLIVA, Zagreb) Praxis Vet 48: 5-14

MENTKEVICH LM, ZHDANOVA LV 1971: Homologous interference by Newcastle disease virus. First stages of interaction of challenge virus with pre-infected cells. Acta Virol 15: 205-209

OIE 2008: World animal health information disease (WAHID) interface. (www.oie.int/wahid-prod/public. php?page= weekly report index\&admin $=0$ )

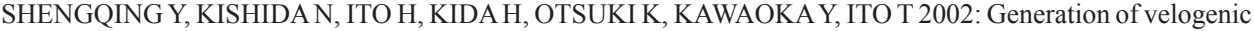
Newcastle disease viruses from a nonpathogenic waterfowl isolate by passaging in chickens. Virology 301: 206-211

TAMÁSI G, VERESS T, KOVÁCS F, DÖMÖTÖR E 1988: A new, simple aerosol immunization technique against Newcastle disease. Acta Vet Hung 36: 185-193

TOTH TE 2000: Nonspecific cellular defence of the avian respiratory system: a review. Dev Comp Immunol 24: 121-139

TOTH TE, SIEGEL PB 1986: Cellular defence of the avian respiratory tract: paucity of the free-residing macrophages in the normal chicken. Avian Dis 30: 67-75

VAN ECK JH 1987: Immunity to Newcastle disease in fowl of different breeds, primarily vaccinated with commercial inactivated oil-emulsion vaccines: a laboratory experiment. Vet Q 9: 296-303

VILLEGAS P, KLEVEN SH 1976: Aerosol vaccination against Newcastle disease. I. Studies on particle size. Avian Dis 20: 179-190 
Plate X

Mazija H. et al.: Immunogenicity ... pp. 137-144

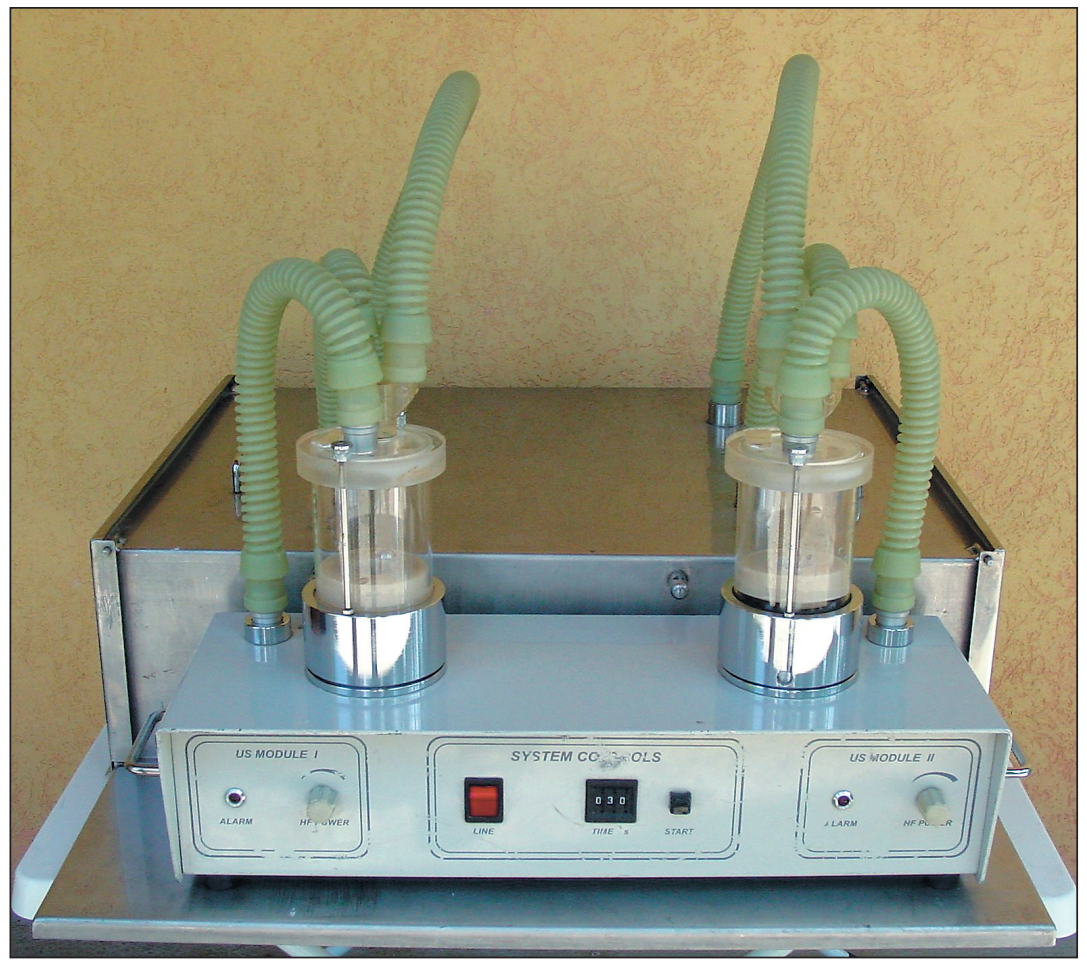

Fig. 1. SONOVAC ${ }^{\circledR} 095$ ultrasonic nebulizer 